\section{The pathologist's perspective on vitreous opacities}

\begin{abstract}
Background Vitreous opacities are diverse in nature. Many underlying diseases are sightthreatening and several are also lethal. This review presents the pathologist's perspective of vitreous opacities, correlates laboratory findings with the underlying disease and recommends safe methods for handling specimens. An aetiological classification of vitreous opacities is also proposed.
\end{abstract}

Methods A gentle fixative such as Cytolyt or HOPE-fixation is required, unless delivery of the vitreous biopsy specimen to the laboratory can be guaranteed within two hours. Cells and other material are precipitated onto slides or into cell blocks by centrifugation. Light microscopy with the May-Grunewald Giemsa stain is enhanced, as necessary, by the use of special stains, such as Congo red for amyloid, Perl's for iron, Periodic Acid-Schiff for microorganisms, and several others. Immunocytological methods enable cell typing, using labels such as CD3 for T-cells in reactive inflammation; CD20 for B-cells in retinal lymphoma; CD34 and myeloperoxidase for myeloid leukaemic cells. The polymerase chain reaction enhances the identification of organisms in endophthalmitis and of immunoglobulin rearrangements in lymphoma.

Results Acquired vitreous opacities can be classified according to their aetiology as: genetic; inflammatory non-infectious; inflammatory infectious; inflammatory iatrogenic; degenerative, traumatic; neoplastic and idiopathic. Non-diagnostic vitreous biopsies, unfortunately, still do occur with the main causes of failure including small sample size; sampling error; inadequate fixation; and leakage from container during transport. Conclusions Vitreous biopsy can profoundly influence the outcome in patients with vitreous opacities. Success depends on close collaboration between clinicians, pathologists and microbiologists. Vitreous samples require proper handling and expert application of a wide range of specialized techniques. Eye (2008) 22, 1318-1329; doi:10.1038/eye.2008.31; published online 14 March 2008

Keywords: vitritis; vitreous inflammation; vitreous infiltrates; ocular lymphoma; retinal lymphoma; vitreoretinal lymphoma

Introduction

The vitreous body is a transparent, extracellular gel, with a complicated structural framework of collagen, soluble proteins, hyaluronic acid, and a water content of $99 \%$. The few cells that are normally present in the vitreous gel are located predominantly in the cortex and consist of hyalocytes, astrocytes, and glial cells. Vitreous abnormalities include opacification,

liquefaction, and shrinkage. ${ }^{1}$

The terminology of visible vitreous abnormalities is confusing. The term 'vitreous opacities' refers to visible structures in the vitreous gel (as opposed to opacities within the vitreous cavity but outside the gel, exemplified by subhyaloid haemorrhage). 'Vitreous infiltrates' imply transport of extraneous material through membranes in the retina. 'Vitreous deposits' would include such infiltrates as well as substances 'precipitating' from within the vitreous itself and becoming visible (eg, synchisis scintillans). 'Floaters' usually refer to visual phenomena experienced by the patient.

The differential diagnosis of vitreous opacities can be difficult, because there are many types of vitreous opacity, several having numerous causes. Biopsy can play an important role, but requires proper handling of specimens and application of a wide range of histopathological and molecular biological techniques.

The aims of this article are to classify the various types of vitreous opacity, and to provide 
an overview of vitreous biopsy, from the pathologist's perspective.

\section{Classification of vitreous opacities}

Traditionally, vitreous opacities were divided aetiologically into two main classes: congenital and acquired, with the latter class being further subdivided into two subclasses, endogenous and exogenous. ${ }^{1}$ As seen in Table 1, there were additional subdivisions of the opacities within each of these subclasses.

With advances in diagnostic and laboratory techniques, our understanding of the aetiology of acquired vitreous opacities has improved, making it necessary for this classification to be revised. Acquired causes of vitreous opacity can be categorized as genetic, inflammatory non-infectious, inflammatory infectious, inflammatory iatrogenic, degenerative, traumatic, neoplastic and idiopathic. These are summarized in Table 2, with corresponding non-exhaustive lists of diseases exemplifying each of the subdivisions.

\section{Sample handling and processing}

Since the underlying pathological lesions resulting in vitreous opacities may be located in differing ocular tissues, such as the uvea or the retina, with possible involvement of the anterior chamber, the histopathologist may receive a variety of specimens, including aqueous tap, vitreous tap, diagnostic vitrectomy specimen, uveal biopsy or subretinal aspirate. In all cases, careful consideration should be given to the handling and examination of the samples, allowing for the application of cytological, immunocytological, molecular biological and microbiological analyses, to optimize the diagnostic yield. ${ }^{2-26}$

Whether or not to fix a vitreous or aqueous sample depends on the clinical question and the time required for transport to the diagnostic laboratory. If it is possible to deliver the vitreous sample within $1 \mathrm{~h}$ to the investigating laboratory, no fixative is required. If, however, longer delays are anticipated, for example, if the sample is being assessed at a remote laboratory, the specimen should be placed in culture medium (eg, bovine serum albumin) or a mild cytofixative, such as Herpes-glutamic acid buffer-mediated Organic solvent Protection Effect (HOPE) fixation ${ }^{27}$ or Cytolyt (Cytyc) for subsequent ThinPrep slide preparation. ${ }^{28}$ The latter two fixatives are preferable to formalin and glutaraldehyde fixation, because they provide superior preservation of cytomorphology, immunoreactivity, and DNA extraction for clonality assessment using the polymerase chain reaction (PCR). Several authors have advised against alcohol fixation of vitreous samples. ${ }^{26,29}$ It is, therefore,
Table 1 Traditional subdivision of vitreous opacities ${ }^{1}$

\begin{tabular}{|c|c|c|}
\hline Class & Subtype & Examples \\
\hline Congenital & & $\begin{array}{l}\text { Remnants of the } \\
\text { hyaloid vasculature }\end{array}$ \\
\hline Endogenous & $\begin{array}{l}\text { (A) Coagula of colloid } \\
\text { basis of gel } \\
\text { (B) Crystalline deposits }\end{array}$ & $\begin{array}{l}\text { (i) Asteroid bodies } \\
\text { (ii) synchisis scintillans }\end{array}$ \\
\hline Exogenous & $\begin{array}{l}\text { (A) Protein } \\
\text { coagula-the plasmoid } \\
\text { vitreous } \\
\text { (B) Amyloid } \\
\text { (C) Cells }\end{array}$ & $\begin{array}{l}\text { (i) Exudative cells } \\
\text { (ii) Blood } \\
\text { (iii) Tissue cells: } \\
\text { epithelial, histiocytic, } \\
\text { glial } \\
\text { (iv) Tumour cells } \\
\text { (v) Pigment: melanotic } \\
\text { \& haematogenous }\end{array}$ \\
\hline
\end{tabular}

worth discussing the case with the investigating laboratory before the specimen is collected, so that the correct fixative and container are used and to make any special arrangements for transport.

Various techniques have been described in the literature for the preparation of vitreous and aqueous specimens for cytomorphological evaluation. ${ }^{4-7,9,10,20,21,26,30-35}$ These include: (1) vitreous 'filtration'; (2) a celloidin bag technique; (3) cytospin and (4) cell block preparation. We are most familiar with the latter two methods, whereby the vitreous is spun at 500 r.p.m. for $5 \mathrm{~min}$, concentrating the cells either onto glass slides or into an agar block or paraffin. Vitreous and aqueous samples may be accompanied by specimens obtained from tissues such as retina and choroid. ${ }^{20,36}$ These solid specimens are usually fixed in buffered formalin, and processed in paraffin using standard procedures.

Depending on the morphological findings of the vitreous samples, various additional special stains or immunocytological markers may be necessary, as summarized in Table 3.

\section{Examination of acellular vitreous samples}

Acellular vitreous samples contain any of the following: condensed vitreous strands; iridescent particles such as asteroid hyalosis (calcium soaps) and synchisis scintillans (cholesterol); amyloid deposits; squames, consisting of conjunctival cells artefactually displaced during the vitrectomy procedure; retained lens fragments following cataract removal and pigment dust (Figure 1). Depending on the initial findings, special stains may include congo red for amyloid, Prussian blue (or Pearl's) stain for iron, etc. (Table 3). 
Table 2 Classification of acquired vitreous opacities with associated causes, cytomorphological changes and recommended immunocytological and molecular biological analyses

\begin{tabular}{|c|c|c|c|c|c|}
\hline Disease & Cause & Morphology & $\begin{array}{l}\text { Relevant special } \\
\text { stains }\end{array}$ & Immunocytology & $\begin{array}{l}\text { Molecular biological } \\
\text { analysis of vitreous }\end{array}$ \\
\hline
\end{tabular}

\section{Genetic \\ Primary non-familial amyloidosis}

Transthyretin gene mutation

Amorphous, dense

pink globular

excrescences

Autosomal

dominantly inherited vitreoretinal disorders (eg, Wagner-Stickler syndrome, snowflake degeneration, familial exudative vitreoretinopathy)

Inflammatory, non-infectious

Pars planitis

Sarcoidosis

Vitiliginous
chorioretinitis (i.e.
Birdshot)
Behçet's syndrome

HLA A29 in 80-90\% cases

Macrophages with cholesterol crystals, scattered small lymphocytes, proteinaceous material

Congo red: material Not required is metachromic, dichroic and birefringent

Cell aggregates of small

T-lymphocytes, macrophages, glial cells, lytic cells

Macrophages and PAS, Grocott, multinucleate giant Warthin-Starry, cells, possibly forming Ziehl-Neelsen to granulomata, scattered exclude fungi and small lymphocytes

mycobacteria

Small T-lymphocytes, macrophages; scattered eosinophils

HLA B5/BW51 Neutrophils,

in $>50 \%$

patients

lymphocytes, plasma cells, monocytes

Crohn's disease

Juvenile xanthogranuloma

Fuchs' cyclitis

Vogt-KoyanagiHarada syndrome

Multiple sclerosis

\section{Sarcoid-like granulomata with admixed lymphocytes \\ PAS, Grocott, Warthin-Starry, Ziehl-Neelsen to exclude fungi and mycobacteria}

Macrophages and multinucleate (Touton) giant cells

Non-specific chronic infiltrates with small lymphocytes, scattered macrophages

Chronic granulomatous inflammation with melanin-containing epithelioid cells and T-cells, scattered plasma cells Non-specific chronic inflammatory cells
PCR to exclude mycobacterial infection
CD68, S100P,

CD1a to differentiate from Langerhan's cell histiocytosis
Bacterial and fungal stains to exclude microorganisms

CD68, S100P,
CD1a to
differentiate from
Langerhan's cell
histiocytosis


Table 2 (Continued)

\begin{tabular}{|c|c|c|c|c|c|}
\hline Disease & Cause & Morphology & $\begin{array}{l}\text { Relevant special } \\
\text { stains }\end{array}$ & Immunocytology & $\begin{array}{l}\text { Molecular biological } \\
\text { analysis of vitreous }\end{array}$ \\
\hline \multicolumn{6}{|l|}{ Inflammatory infectious } \\
\hline \multicolumn{6}{|l|}{ Bacterial } \\
\hline Endophthalmitis $^{a}$ & See text & Abudant neutrophils & Gram stain & & \\
\hline Tuberculosis & $\begin{array}{l}\text { Mycobacterium } \\
\text { tuberculosis }\end{array}$ & $\begin{array}{l}\text { Macrophages and } \\
\text { multinucleate giant } \\
\text { cells with granulomata, } \\
\text { scattered small } \\
\text { lymphocytes }\end{array}$ & $\begin{array}{l}\text { Ziehl-Neelsen for } \\
\text { acid-fast bacilli }\end{array}$ & & $\begin{array}{l}\text { PCR directed at } \\
\text { mycobacteria }\end{array}$ \\
\hline Whipple's disease & $\begin{array}{l}\text { Tropheryma } \\
\text { whipplei }\end{array}$ & Foamy macrophages & $\begin{array}{l}\text { PAS for } \\
\text { cytoplasmic } \\
\text { inclusion bodies }\end{array}$ & $\begin{array}{l}\text { Ab. against } \\
\text { causative agent }\end{array}$ & \\
\hline \multicolumn{6}{|l|}{ Fungal } \\
\hline Endophthalmitis & $\begin{array}{l}\text { Candida sp } \\
\text { Aspergillus sp } \\
\text { Cryptococcus } \\
\text { neoformans } \\
\text { Fusarium }\end{array}$ & $\begin{array}{l}\text { Numerous mixed } \\
\text { macrophages and } \\
\text { neutrophilic } \\
\text { granulocytes; possibly } \\
\text { granulomatous; } \\
\text { fibrin-platelet } \\
\text { aggregates; necrotic } \\
\text { debris }\end{array}$ & $\begin{array}{l}\text { PAS, Grocott, } \\
\text { Warthin-Starry, } \\
\text { Gomori to } \\
\text { demonstrate fungal } \\
\text { hyphae and spores }\end{array}$ & & \\
\hline \multicolumn{6}{|l|}{ Viral } \\
\hline Chorioretinitis & & $\begin{array}{l}\text { Cytomegalovirus } \\
\text { Herpes simplex virus } \\
\text { Varicella zoster }\end{array}$ & $\begin{array}{l}\text { Non-specific } \\
\text { chronic infiltrates } \\
\text { with small } \\
\text { lymphocytes, } \\
\text { scattered } \\
\text { macrophages, } \\
\text { possibly forming } \\
\text { granulomata; } \\
\text { background lytic } \\
\text { cells }\end{array}$ & & $\begin{array}{l}\text { PCR directed against } \\
\text { viruses }\end{array}$ \\
\hline \multicolumn{6}{|l|}{ Parasitic } \\
\hline $\begin{array}{l}\quad \text { Toxoplasmosis } \\
\text { Toxocariasis } \\
\text { Ocular cysticerosis }\end{array}$ & $\begin{array}{l}\text { T. gondii } \\
\text { T. canis } \\
\text { T. solium }\end{array}$ & $\begin{array}{l}\text { Chronic inflammatory } \\
\text { cells with numerous } \\
\text { eosinophils, } \\
\text { lymphocytes, plasma } \\
\text { cells \& macrophages }\end{array}$ & $\begin{array}{l}\text { PAS to demonstrate } \\
\text { parasites }\end{array}$ & & $\begin{array}{l}\mathrm{PCR} \text { directed against } \\
\text { microorganisms }\end{array}$ \\
\hline \multicolumn{6}{|l|}{ Spirochaetal } \\
\hline $\begin{array}{c}\text { Syphilis } \\
\text { Lyme disease }\end{array}$ & $\begin{array}{l}\text { Treponema } \\
\text { pallidum } \\
\text { Borrelia } \\
\text { burgdorferi }\end{array}$ & $\begin{array}{l}\text { Non-specific chronic } \\
\text { inflammatory cells }\end{array}$ & $\begin{array}{l}\text { Silver stains to } \\
\text { demonstrate } \\
\text { spirochaetes }\end{array}$ & & $\begin{array}{l}\text { PCR directed against } \\
\text { microorganisms }\end{array}$ \\
\hline $\begin{array}{l}\text { Inflammation, iatrogenic } \\
\text { eg, ICCE, pan-retinal } \\
\text { photocoagulation, } \\
\text { cryotherapy }\end{array}$ & & $\begin{array}{l}\text { Non-specific chronic } \\
\text { inflammatory cells, } \\
\text { RPE cells, retinal } \\
\text { fragments, } \\
\text { proteinaceous deposits }\end{array}$ & & & \\
\hline \multicolumn{6}{|l|}{ Degenerative } \\
\hline Vitreous detachment & & $\begin{array}{l}\text { Non-specific chronic } \\
\text { inflammatory cells }\end{array}$ & & & \\
\hline Pigment granules & $\begin{array}{l}\text { Melanocytic or } \\
\text { haemorrhage }\end{array}$ & $\begin{array}{l}\text { Pigment granules, } \\
\text { dispersed or within } \\
\text { vitreous strands }\end{array}$ & $\begin{array}{l}\text { Perl's to exclude/ } \\
\text { detect haemosiderin }\end{array}$ & & \\
\hline
\end{tabular}


Table 2 (Continued)

\begin{tabular}{|c|c|c|c|c|c|}
\hline Disease & Cause & Morphology & $\begin{array}{l}\text { Relevant special } \\
\text { stains }\end{array}$ & Immunocytology & $\begin{array}{l}\text { Molecular biological } \\
\text { analysis of vitreous }\end{array}$ \\
\hline \multicolumn{6}{|l|}{ Traumatic } \\
\hline \multicolumn{2}{|l|}{$\begin{array}{l}\text { Vitreous detachment } \\
\text { (eg, traumatic avulsion of } \\
\text { vitreous base) }\end{array}$} & \multicolumn{4}{|l|}{$\begin{array}{l}\text { Non-specific chronic } \\
\text { inflammatory cells }\end{array}$} \\
\hline \multicolumn{2}{|l|}{ Haemorrhage } & $\begin{array}{l}\text { Clumps or strands of } \\
\text { erythrocytes in fresh } \\
\text { haemorrhage; } \\
\text { dispersed "ghost" } \\
\text { cells with scattered } \\
\text { macrophages in older } \\
\text { haemorrhage }\end{array}$ & \multirow[t]{2}{*}{$\begin{array}{l}\text { Perl's for } \\
\text { haemosiderin } \\
\text { deposition; bacterial } \\
\text { \& fungal stains to } \\
\text { exclude underlying } \\
\text { causative agents }\end{array}$} & \multirow[t]{2}{*}{$\begin{array}{l}\text { Only } \\
\text { appropriate in } \\
\text { cases of } \\
\text { suspected } \\
\text { underlying } \\
\text { malignancy } \\
\text { (see below). }\end{array}$} & \multirow[t]{2}{*}{$\begin{array}{l}\text { Only appropriate in } \\
\text { suspected underlying } \\
\text { lymphoma (see below) } \\
\text { or viral infection }\end{array}$} \\
\hline $\begin{array}{l}\text { Sympathetic } \\
\text { ophthalmia }\end{array}$ & & $\begin{array}{l}\text { Chronic granulomatous } \\
\text { inflammation with } \\
\text { melanin-containing } \\
\text { epithelioid cells and } \\
\text { T-cells, scattered } \\
\text { plasma cells: varying } \\
\text { amount of eosinophils }\end{array}$ & & & \\
\hline \multicolumn{6}{|l|}{ Neoplastic } \\
\hline \multicolumn{6}{|l|}{ Primary } \\
\hline Retinoblastoma & & $\begin{array}{l}\text { Small atypical "blue } \\
\text { cell" neoplasm cells }\end{array}$ & & $\begin{array}{l}\text { Synaptophysin } \\
\text { positive }\end{array}$ & \\
\hline Retinal lymphoma & & Atypical lymphocytes, & & B-cell antigens & IgH-PCR IL10:IL6 \\
\hline Retinovitreal lymphoma & & macrophages, lytic cells & & (CD20, CD79a); & (ELISA) \\
\hline Vitreal lymphoma & & & & IgH or IgL; Ki-67 & \\
\hline Uveal melanoma & & $\begin{array}{l}\text { Tumour cells } \\
\text { haemorrhage }\end{array}$ & & MelanA, HMB-45 & \\
\hline \multicolumn{6}{|l|}{ Neoplastic } \\
\hline \multicolumn{6}{|l|}{ Secondary } \\
\hline $\begin{array}{l}\text { Metastatic } \\
\text { carcinoma }\end{array}$ & & $\begin{array}{l}\text { Clumps of varying- } \\
\text { sized atypical cells }\end{array}$ & & $\begin{array}{l}\text { Pancytokeratin } \\
\text { Cytokeratin } \\
\text { subtypes }\end{array}$ & \\
\hline \multicolumn{6}{|l|}{ cutaneous melanoma } \\
\hline $\begin{array}{l}\text { Secondary ocular } \\
\text { involvement by } \\
\text { leukaemia }\end{array}$ & & $\begin{array}{l}\text { Atypical myeloblasts } \\
\text { with or without } \\
\text { maturation }\end{array}$ & & $\begin{array}{l}\text { Myeloperoxidase, } \\
\text { CD34, CD117 }\end{array}$ & \\
\hline $\begin{array}{l}\text { Secondary ocular } \\
\text { involvement by } \\
\text { lymphoma }\end{array}$ & & Atypical lymphocytes & & $\begin{array}{l}\text { B-cell antigens } \\
\text { (CD20, CD79a), } \\
\text { T-cell antigens } \\
\text { (CD3), plasma } \\
\text { cell marker } \\
\text { (CD138, IgL) }\end{array}$ & IgH-PCR \\
\hline \multicolumn{6}{|l|}{ Idiopathic } \\
\hline Asteroid hyalosis & $\begin{array}{l}\text { Calcium } \\
\text { pyrophophate- } \\
\text { spheres }\end{array}$ & $\begin{array}{l}\text { Round varying-sized } \\
\text { bodies with minimal } \\
\text { inflammatory reaction }\end{array}$ & Von Kossa & & \\
\hline Synchysis scintillans & $\begin{array}{l}\text { Cholesterol } \\
\text { crystals }\end{array}$ & $\begin{array}{l}\text { Crystals with minimal } \\
\text { inflammatory reaction }\end{array}$ & & & \\
\hline
\end{tabular}

$\mathrm{Ab}=$ antibody; $\mathrm{CD}=$ cluster of differentiation; $\mathrm{ICCE}=$ intracapsular cataract extraction; IgH-PCR $=$ Immunoglobulin heavy chain polymerase chain reaction; PAS = periodic acid Schiff; $\mathrm{PCR}=$ polymerase chain reaction; $\mathrm{RPE}=$ retinal pigment epithelium.

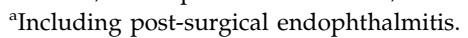


Table 3 Useful stains in the assessment of vitreous biopsies

\begin{tabular}{|c|c|c|}
\hline Conventional Histochemical Stains & Detects & Examples/comments \\
\hline $\begin{array}{l}\text { Morphological stains (eg, May Grunewald-Giemsa, } \\
\text { modified Papanicolou) }\end{array}$ & Morphology & \\
\hline Giemsa & $\begin{array}{l}\text { Bacteria } \\
\text { Fungi } \\
\text { Parasites } \\
\text { Protozoa }\end{array}$ & $\begin{array}{l}\text { Neisseria sp. } \\
\text { Actinomyces sp. } \\
\text { Toxoplasmosis } \\
\text { Leishmania tropica }\end{array}$ \\
\hline Gram Twort & $\begin{array}{l}\text { Gram-positive } \\
\text { bacteria (blue) } \\
\text { Gram-negative } \\
\text { bacteria (red) }\end{array}$ & \\
\hline \multirow{2}{*}{$\begin{array}{l}\text { Periodic Acid-Schiff (PAS) with or without diastase } \\
\text { digestion (d-PAS) }\end{array}$} & Bacteria & Tropheryma whipplei \\
\hline & $\begin{array}{l}\text { Fungi } \\
\text { Parasites }\end{array}$ & $\begin{array}{l}\text { Candida sp. } \\
\text { T. gondii }\end{array}$ \\
\hline $\begin{array}{l}\text { Silver stains (eg, Gomori's methenamine silver; } \\
\text { Grocott) }\end{array}$ & Fungi & \\
\hline Mucicarmine & Fungi & Encapsulated fungi eg, Cryptococcus neoformans \\
\hline (Modified) Ziehl-Neelsen & $\begin{array}{l}\text { Mycobacteria } \\
\text { Nocardia }\end{array}$ & $\begin{array}{l}\text { M. tuberculosis } \\
\text { M. leprae }\end{array}$ \\
\hline Warthin starry & $\begin{array}{l}\text { Bacteria } \\
\text { Fungi } \\
\text { Spirochaetes }\end{array}$ & $\begin{array}{l}\text { Helicobacter sp. } \\
\text { Treponema pallidum }\end{array}$ \\
\hline Perl's prussian blue & $\begin{array}{l}\text { Haemosiderin (ferric } \\
\text { iron) }\end{array}$ & \\
\hline Congo red & $\begin{array}{l}\text { Amyloid } \\
\text { Parasites }\end{array}$ & $\begin{array}{l}\text { Green birefringence } \\
\text { Taenia echinococcus }\end{array}$ \\
\hline \multicolumn{3}{|l|}{ Immunohistochemistry } \\
\hline CD3 & Pan T-cell marker & \\
\hline CD20 & B-cell marker & Negative on precursor B-cells and plasma cells \\
\hline CD68 & $\begin{array}{l}\text { Pan-macrophage } \\
\text { marker }\end{array}$ & \\
\hline MelanA, HMB-45 & Melanocyte markers & \\
\hline Pancytokeratin & Epithelial cells & eg, MNF-116 \\
\hline Anti-Cytomegalovirus & CMV & $\begin{array}{l}\text { Against early and late antigens allowing for detection in } \\
\text { nucleus and cytoplasm }\end{array}$ \\
\hline $\begin{array}{l}\text { Anti-Herpes simplex viruses I and II } \\
\text { Anti-Varicella virus } \\
\text { Anti-Trophyrema whipplei }\end{array}$ & $\begin{array}{l}\text { HSV I and II } \\
\text { Varicella } \\
\text { Whipple's disease }\end{array}$ & Polyclonal antibody \\
\hline
\end{tabular}

\section{Cellular vitreous samples}

On microscopy, cells in vitreous samples can be categorized as: haemorrhagic, inflammatory non-infectious, inflammatory infectious and neoplastic.

\section{Haemorrhage}

Vitreous specimens with haemorrhage predictably contain varying amounts of erythrocytes, 'ghost cells' haemosiderin-laden macrophages and acellular eosinophilic material, in various proportions, depending on the age of the haemorrhage. (Figure 2). Neoplastic cells or microorganisms within the haemorrhage may reveal the underlying cause.

\section{Inflammatory non-infectious vitritis}

Inflammatory non-infectious vitreous cells consist predominantly of small T-lymphocytes, which are usually of the CD4 + helper type. ${ }^{9}$ Varying proportions 

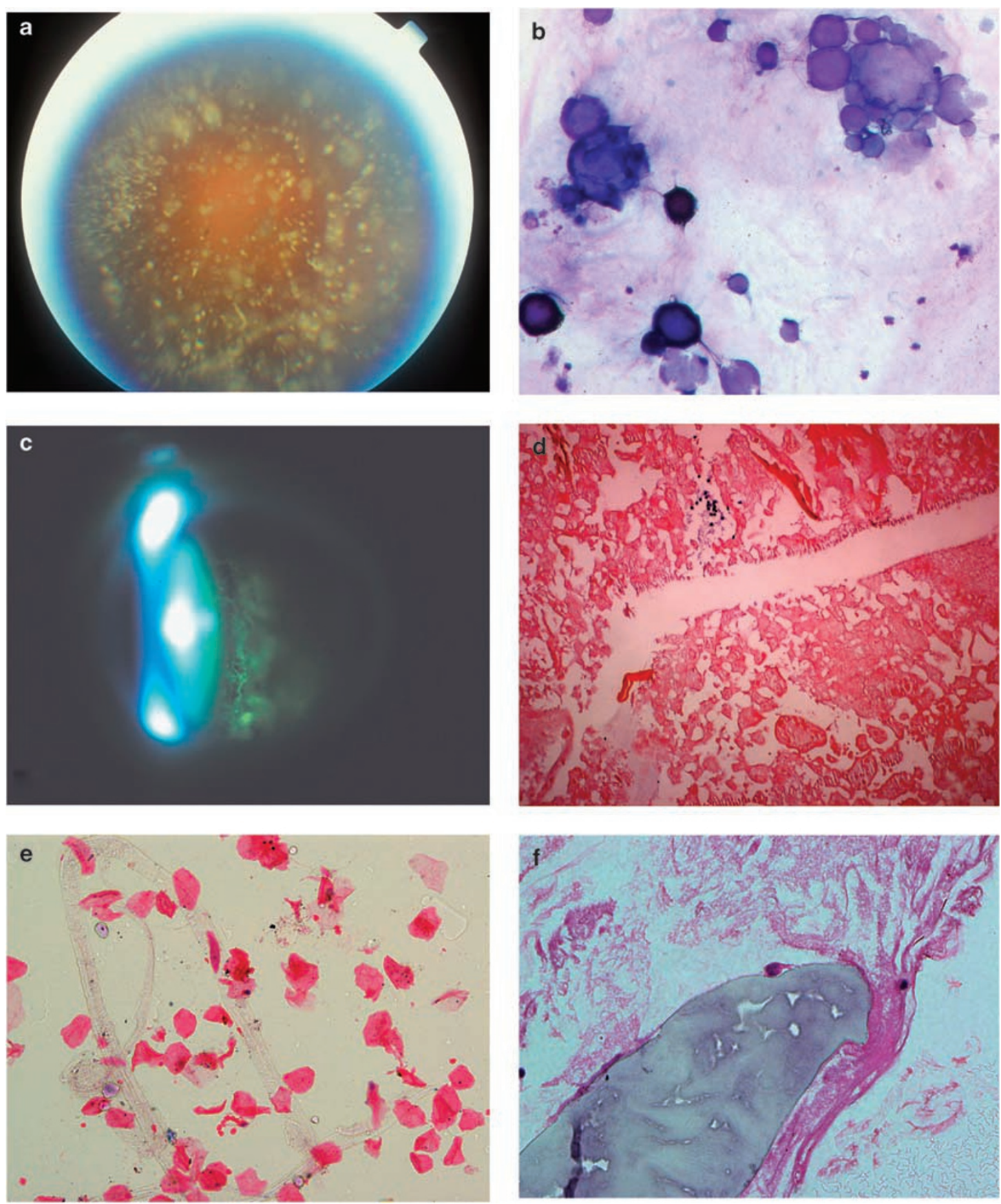

Figure 1 (a) Clinical photograph of asteroid hyalosis in a patient with uveal melanoma (Courtesy of Professor Bertil Damato); (b) Cytospin of a diagnostic vitrectomy in another patient showing the circular spheres seen in asteroid hyalosis (May Grunewald Giemsa); (c) Clinical photograph of a patient with primary amyloidosis of the vitreous; (d) Congo red stain of the centrifuged vitreous specimen demonstrating positive material, which was bi-refringent under polarized light; (e) Conjunctival squames, artificially displaced into the vitreous on sampling (HE); (f) Retained lens fragments in a vitreous biopsy with a mild foreign-body inflammatory reaction (HE).

of admixed macrophages, monocytes, plasma cells and neutrophils may be present (Figure 2). Once malignant cells and microorganisms have been excluded, the diagnosis may amount only to 'chronic non-specific vitritis', despite the use of special stains, immunocytology and/or PCR for clonality. In such cases, the clinical history and examination findings are especially important. 
Inflammatory, infectious vitritis

Abundant neutrophils suggest bacterial (suppurative) endophthalmitis, most commonly caused by organisms such as Streptococcus sp, Staphylococcus aureus, Staphylococcus epidermis, coagulase-negative staphylococcus, Neisseria sp, Bacillus cereus, Haemophilus influenzae, Propionibacterium acnes, Pseudomonoas aeruginosa, Klebsiella pneumoniae and Escerichia coli. ${ }^{4}$ Microbiological cultures or molecular biological techniques are usually necessary for the exact identification of the genus and determination of antibiotic sensitivities, ${ }^{37}$ however, bacterial stains of vitreous specimens may identify the causative agent should cultures be negative. It is important to note that neutrophilic infiltrates in the aqueous and/or vitreous can occur with non-bacterial conditions such as Behçet's disease.

The presence of eosinophils in the vitreous suggests conditions such as nematode-induced endophthalmitis (eg, Toxocara canis), sympathetic ophthalmia, Lyme disease, Eale's disease, and, rarely, birdshot retinochoroidopathy or chronic eosinophilic myeloid leukaemia. ${ }^{38}$ Scattered eosinophils with non-specific vitritis can occur in Toxoplasmic retinochoroiditis. In this condition, the bradyzoites and tachyzoites may be seen occasionally in vitreous samples (Figure 2) but more often in the outer layers of the retina in chorioretinal biopsies stained with periodic acid-Schiff (PAS).

Additional molecular analyses of ocular fluids are often required for confirmation in this condition. ${ }^{39}$

A predominance of macrophages in the vitreous sample may occur in Whipple's disease, ocular toxoplasmosis, and endophthalmitis due to Mycobacterium avium, Histoplasmosis capsulatum, Pneumocystis carinii, Cryptococcus and Blastomyces. In these conditions, fungal stains such as PAS and mucicarmine may reveal cytoplasmic inclusions or cysts of particular sizes and shape. (Figure 2) This allows for a morphological suggestion of the possible causative microorganism, to be confirmed however, with immunocytology, cultures and/or PCR.

Macrophages and multinucleated giant cells suggest a granulomatous process (Figure 2), caused by fungal and mycobacterial infections. The most common fungi causing fungal endophthalmitis include Candida sp, Aspergillus fumigatus and flavus, as well as Cryptococcus neoformans (Figure 2) (Table 2). ${ }^{4,40}$ Acid-fast bacilli, highlighted with Ziehl-Neelsen, are rarely observed in aqueous and vitreous samples but may be found intracytoplasmically within macrophages or retinal pigment epithelial cells in tissue biopsies. ${ }^{41}$ Granulomatous inflammation with negative staining for fungi, mycobacteria and other microorganisms suggests sarcoidosis although the history and clinical findings should be taken into account. Tissue biopsies from the uvea may confirm this diagnosis, and may also exclude juvenile xanthogranulomatosis in younger patients.

Exceptionally rarely, intranuclear and intracytoplasmic viral inclusion bodies (eg, cytomegalovirus or Herpes simplex) may be demonstrated in association with necrotic cells in the vitreous sample. Such inclusion bodies are, however, more likely to be demonstrated in chorioretinal biopsies, using immunohistochemical or immunofluorescence techniques. PCR analysis of ocular fluid samples may expedite the diagnosis and treatment of such conditions, which is important as the retinitis can progress rapidly. ${ }^{11,15,16,42,43}$

Syphilis, once the main cause of vitreous opacities, ${ }^{1}$ accounts for only about $1 \%$ of all vitreous opacities but is increasing in incidence, particularly in the HIV-positive population, ${ }^{44}$ and should always be considered in the differential diagnosis of an inflammatory cellular vitreous infiltrate.

\section{Neoplastic disease}

Malignant neoplasms can simulate vitritis ('masquerade syndrome'). They include primary ocular tumours such as retinal lymphoma (also known as 'primary intraocular lymphoma') and retinoblastoma, as well as diseases such as leukaemia, metastatic carcinomas and metastatic cutaneous melanomas. ${ }^{45-50}$. The latter are most often localized to the choroid, but can produce brown 'cannonballs' of tumour cell aggregates within the vitreous. Ocular metastases arise most commonly from lung and breast in men and women, respectively. Other primary sites include kidney and prostate.

The main 'masquerader', however, is retinal lymphoma, which is located primarily within the subretinal space. This often seeds into the vitreous (ie, 'retinovitreal lymphoma') and may be located purely within the vitreous (ie, 'vitreal lymphoma').

Cytomorphological examination of vitreous infiltrates in retinal lymphoma demonstrates medium-to-large cells with minimal cytoplasm, pleomorphic or round nuclei and prominent nucleoli (Figure 3). Necrotic material and macrophages are commonly present. Immunocytology shows the neoplastic cells to express B-cell antigens (CD79a, CD20, PAX-5) in the majority of cases. Many of these cells stain positively with the MIB-1 antibody, which indicates a high growth fraction, that is, a highgrade of malignancy (Figure 3). The diagnosis of lymphoma is supported by demonstration of cellular monoclonality, with monotypic expression of either a light and/or heavy chain of the immunoglobulin gene (usually IgM). Should sufficient material be available for examination, investigation of the vitreous specimens for rearrangements of the immunoglobulin heavy chain gene using PCR provides further evidence of the neoplastic 
nature of the lymphocytic infiltrate in retinal lymphoma. ${ }^{17,18,20,22,25,35,49,51}$ Biochemical analysis of the vitreous specimen for interleukin ratios (IL10: IL6) may also support the diagnosis of retinal lymphoma. ${ }^{52-54}$ If possible, retinal lymphoma should be distinguished from other types of intraocular lymphoma, namely primary
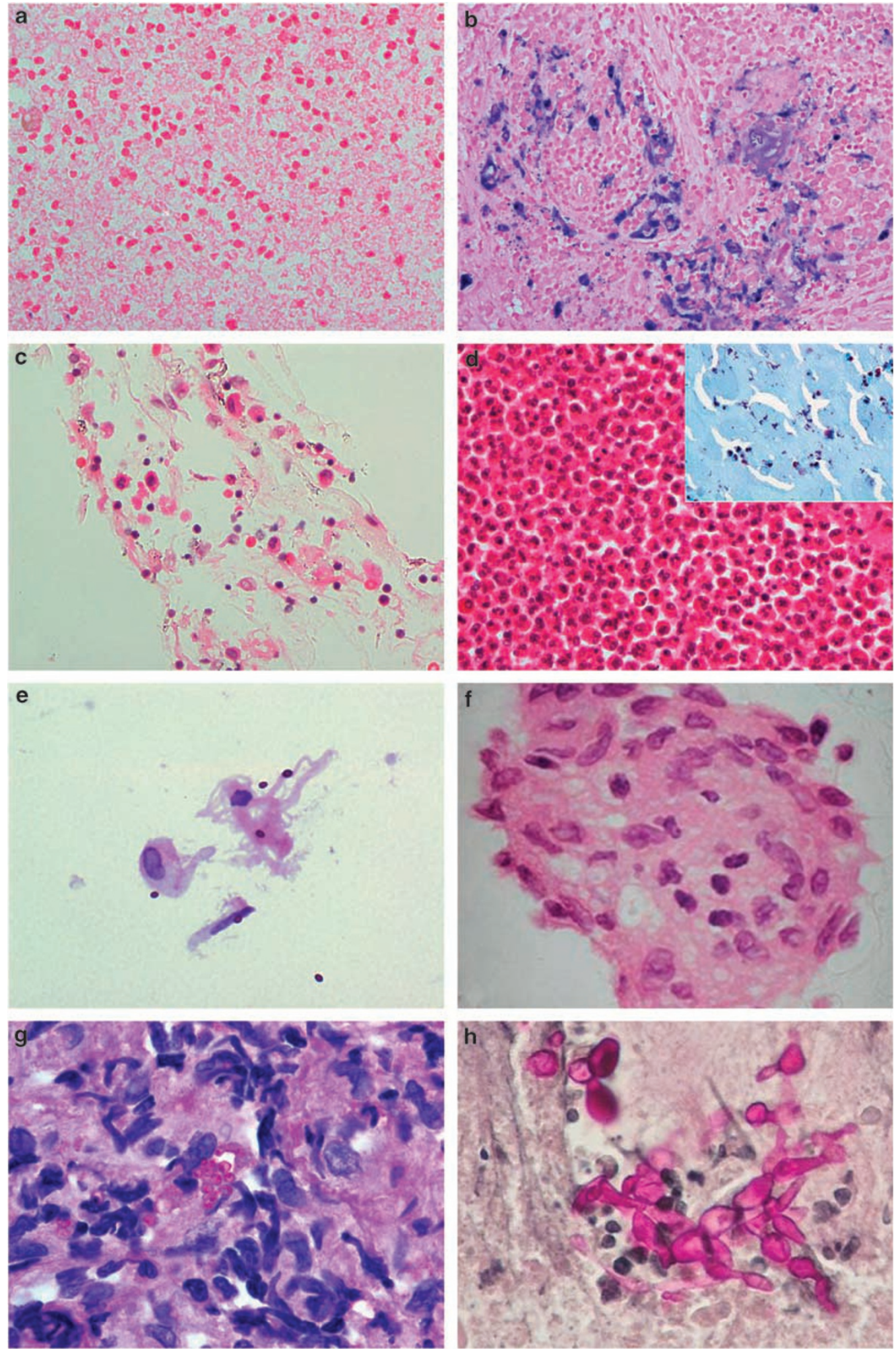
uveal lymphoma and secondary (metastatic) intraocular lymphoma. The reader is referred to detailed reviews outlining the morphological and immunocytological characteristics of these rare entities. ${ }^{55,56}$

\section{Non-diagnostic vitreous biopsy}

A 'negative' vitreous biopsy, which is particularly problematic in suspected cases of intraocular

lymphoma, ${ }^{57}$ has several causes. First of all, the vitreous
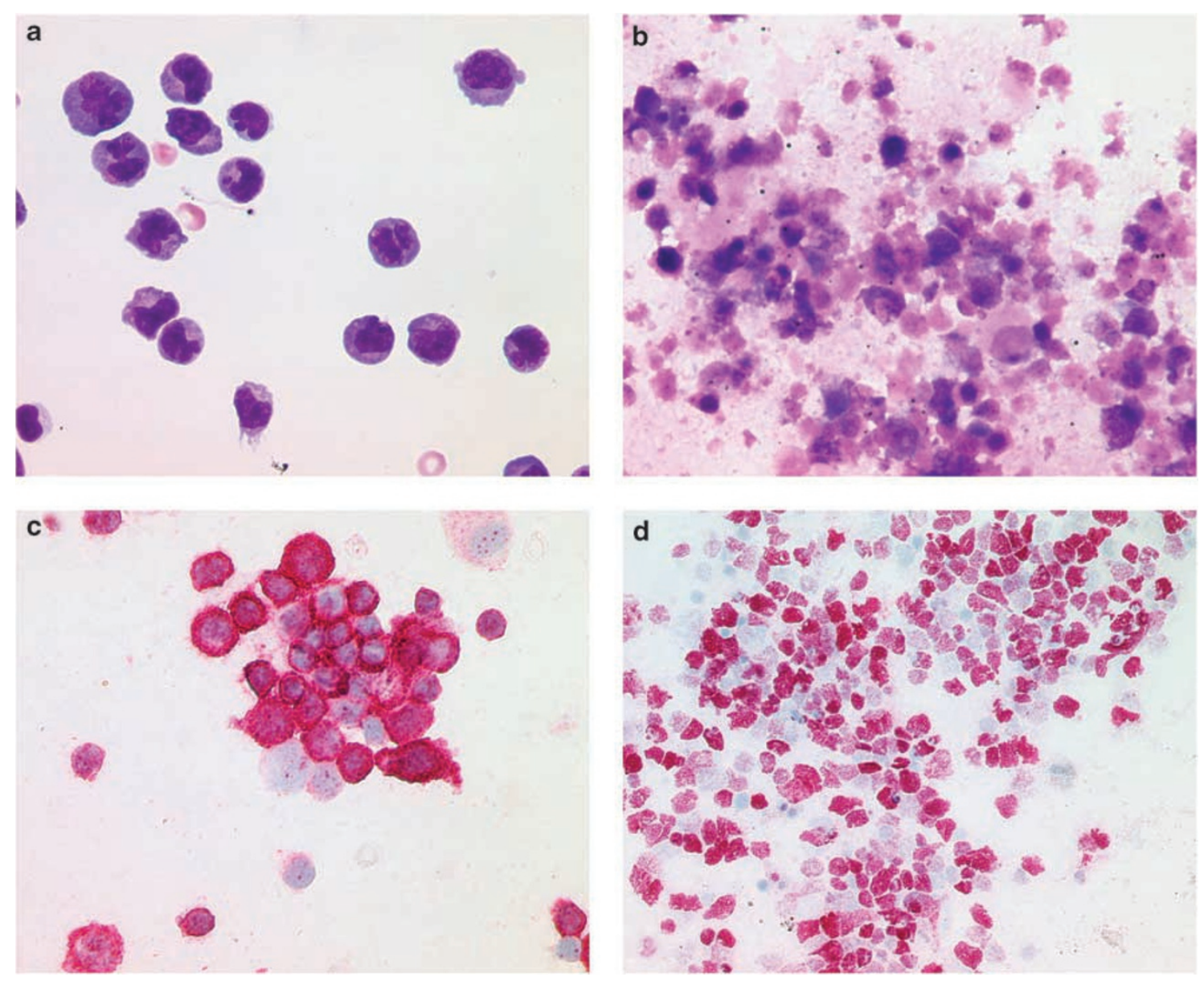

Figure 3 (a and b) Two vitrectomy specimens with varying degrees of cellularity demonstrating atypical lymphocytes with convoluted nuclei on a background of lytic cells and scavenging macrophages (May Grunewald Giemsa); (c) Retinovitreal lymphoma cells with clear membranous positivity for the B-cell antigen, CD20 (APAAP stain); (d) MIB-1 antibody directed against the Ki-67 antigen, showing a high growth fraction in retinovitreal lymphoma cells, indicating the high degree of malignancy (APAAP stain).

Figure 2 (a) Resolving vitreous haemorrhage with some scattered melanomacrophages (HE stain); (b) Perl's stain showing haemosiderin in an older vitreous haemorrhage; (c) Non-specific inflammatory infiltrate in 'chronic non-specific vitritis', comprising macrophages, plasma cells, lymphocytes and occasional neutrophils (HE stain); (d) Suppurative bacterial endophthalmitis (HE) with evidence of Gram-positive organisms (inset); (e) Pars plana vitrectomy sample with macrophages and scattered bradyzoites (PAS stain); (f) Granulomatous vitritis (HE); the Ziehl-Neelsen stain was negative, and the clinical findings were suggestive of sarcoidosis; (g) Chorioretinal biopsy demonstrating a granulomatous inflammation with evidence of microorganisms, morphologically consistent with Histoplasma capsulatum (PAS stain); (h) Agar cell block of a vitrectomy sample showing fungal elements, consistent with Candida sp (PAS stain).

gel may not contain any material of diagnostic relevance, as in primary uveal lymphomas and some cases of retinal lymphoma where the tumour cells are confined to the Secondly, the patient may have been treated with steroids prior to vitrectomy, increasing the cell fragility. Thirdly, perhaps because of leakage from a poorly-sealed container during transport to the laboratory. Fourthly, the specimen may not be handled properly, for example, not

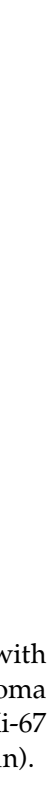


being placed in the correct fixative or being left unfixed for an excessive time. Fifthly, the specimen may be lost during laboratory processing, perhaps as a result of a technical error. Most of these problems can be avoided by taking the precautions already mentioned in this article. Whenever a non-diagnostic biopsy occurs, it is especially important for the clinician and pathologist to confer without delay, so that any errors can be avoided if the investigation is repeated.

\section{Conclusions}

The diagnosis of vitreous opacities demands close collaboration between the clinician, the pathologist and the microbiologist. This involves documentation of all relevant clinical information in the pathology request form, comprehensive and up-to-date guidelines and protocols, timely discussions between the various specialists (for example, telephone communications just before a vitreous biopsy is performed), regular audits and multidisciplinary meetings. The laboratory investigation of vitreous specimens is demanding and depends not only on a pathologist with special expertise but also on the support of experienced technical staff capable of using a wide range of investigations.

\section{Acknowledgements}

I am indebted to Professor Bertil Damato for his reading and discussion of the paper as well as for his aid in lecture material. I thank Professor Stefan Seregard and Associate Professor O Sangren for the provision of the pictures of primary amyloidosis of the vitreous; Professor Karin Loeffler for the microphotograph of the fungal endophthalmitis. Finally, I am grateful to PD Dr med Heinrich Heimann for the provision of clinical photographs for the lecture at the Cambridge Symposium on 7 September 2007.

\section{References}

1 Duke-Elder S. Diseases of the Vitreous Body. Edited by S D-E Henry Kimpton: London, 1969, pp 315-375.

2 Klingele TG, Hogan MJ. Ocular reticulum cell sarcoma. Am J Ophthalmol 1975; 79: 39-47.

3 Carroll DM, Franklin RM. Vitreous biopsy in uveitis of unknown cause. Retina 1981; 1: 245-251.

4 Green WR. Diagnostic cytopathology of ocular fluid specimens. Ophthalmology 1984; 91: 726-749.

5 Mandell DB, Levy JJ, Rosenthal DL. Preparation and cytologic evaluation of intraocular fluids. Acta Cytol 1987; 31: 150-158.
6 Ljung BM, Char D, Miller TR, Deschenes J. Intraocular lymphoma. Cytologic diagnosis and the role of immunologic markers. Acta Cytol 1988; 32: 840-847.

7 Augsburger JJ. Invasive diagnostic techniques for uveitis and simulating conditions. Trans Am Ophthalmol Soc 1990; 88: 89-104; discussion 104-107.

8 Wilson DJ, Braziel R, Rosenbaum JT. Intraocular lymphoma. Immunopathologic analysis of vitreous biopsy specimens. Arch Ophthalmol 1992; 110: 1455-1458.

9 Davis JL, Solomon D, Nussenblatt RB, Palestine AG, Chan CC. Immunocytochemical staining of vitreous cells. Indications, techniques, and results. Ophthalmology 1992; 99: 250-256.

10 Obata H, Horiuchi H, Tsuru T. Clinical application of new membrane filter for cytopathological diagnosis in ophthalmology. Jpn J Ophthalmol 1993; 37: 344-351.

11 Garweg J, Fenner T, Bohnke M, Schmitz H. An improved technique for the diagnosis of viral retinitis from samples of aqueous humor and vitreous. Graefes Arch Clin Exp Ophthalmol 1993; 231: 508-513.

12 Shields JA, Shields CL, Ehya H, Eagle Jr RC, De Potter P. Fine-needle aspiration biopsy of suspected intraocular tumors. The 1992 Urwick Lecture. Ophthalmology 1993; 100: 1677-1684.

13 Abe T, Tsuchida K, Tamai M. A comparative study of the polymerase chain reaction and local antibody production in acute retinal necrosis syndrome and cytomegalovirus retinitis. Graefes Arch Clin Exp Ophthalmol 1996; 234: 419-424.

14 Verbraeken H. Diagnostic vitrectomy and chronic uveitis. Graefes Arch Clin Exp Ophthalmol 1996; 234(Suppl 1): S2-S7.

15 Doornenbal P, Seerp Baarsma G, Quint WG, Kijlstra A, Rothbarth PH, Niesters HG. Diagnostic assays in cytomegalovirus retinitis: detection of herpesvirus by simultaneous application of the polymerase chain reaction and local antibody analysis on ocular fluid. Br J Ophthalmol 1996; 80: 235-240.

16 Knox CM, Chandler D, Short GA, Margolis TP. Polymerase chain reaction-based assays of vitreous samples for the diagnosis of viral retinitis. Use in diagnostic dilemmas. Ophthalmology 1998; 105: 37-44; discussion 44-35.

17 Shen DF, Zhuang Z, LeHoang P, Boni R, Zheng S, Nussenblatt RB et al. Utility of microdissection and polymerase chain reaction for the detection of immunoglobulin gene rearrangement and translocation in primary intraocular lymphoma. Ophthalmology 1998; 105: 1664-1669.

18 White VA, Gascoyne RD, Paton KE. Use of the polymerase chain reaction to detect $\mathrm{B}$ - and T-cell gene rearrangements in vitreous specimens from patients with intraocular lymphoma. Arch Ophthalmol 1999; 117: 761-765.

19 Dworkin LL, Gibler TM, Van Gelder RN. Real-time quantitative polymerase chain reaction diagnosis of infectious posterior uveitis. Arch Ophthalmol 2002; 120: 1534-1539.

20 Coupland SE, Bechrakis NE, Anastassiou G, Foerster AM, Heiligenhaus A, Pleyer U et al. Evaluation of vitrectomy specimens and chorioretinal biopsies in the diagnosis of primary intraocular lymphoma in patients with Masquerade syndrome. Graefes Arch Clin Exp Ophthalmol 2003; 241: 860-870.

21 Lobo A, Lightman S. Vitreous aspiration needle tap in the diagnosis of intraocular inflammation. Ophthalmology 2003; 110: 595-599. 
22 Davis JL. Diagnosis of intraocular lymphoma. Ocul Immunol Inflamm 2004; 12: 7-16.

23 Zaldivar RA, Martin DF, Holden JT, Grossniklaus HE. Primary Intraocular Lymphoma. Clinical, cytologic and flow cytometric analysis. Ophthalmology 2004; 111(9): 1762-1767.

24 Davis JL, Miller DM, Ruiz P. Diagnostic testing of vitrectomy specimens. Am J Ophthalmol 2005; 140: 829-899.

25 Lobo A, Okhravi N, Adamson P, Clark BJ, Lightman S. Protocol for the use of polymerase chain reaction in the detection of intraocular large B-cell lymphoma in ocular samples. J Mol Diagn 2007; 9: 113-121.

26 Karma A, von Willebrand EO, Tommila PV, Paetau AE, Oskala PS, Immonen IJ. Primary intraocular lymphoma: improving the diagnostic procedure. Ophthalmology 2007; 114: $1372-1377$.

27 Coupland SE, Perez-Canto A, Hummel M, Stein H, Heimann H. Assessment of HOPE fixation in vitrectomy specimens in patients with chronic bilateral uveitis (masquerade syndrome). Graefes Arch Clin Exp Ophthalmol 2005; 243: 847-852.

28 Wang HH, Sovie S, Trawinski G, Garcia LW, Abu-Jawdeh $\mathrm{GM}$, Upton $\mathrm{M}$ et al. ThinPrep processing of endoscopic brushing specimens. Am J Clin Pathol 1996; 105: 163-167.

29 Conlon MR, Craig I, Harris JF, Molinaro P, Ventresca M, Gonder JR. Effect of vitrectomy and cytopreparatory techniques on cell survival and preservation. Can J Ophthalmol 1992; 27: 168-171.

30 Michels RG, Knox DL, Erozan YS, Green WR. Intraocular reticulum cell sarcoma. Diagnosis by pars plana vitrectomy. Arch Ophthalmol 1975; 93: 1331-1335.

31 Engel HM, Green WR, Michels RG, Rice TA, Erozan YS. Diagnostic vitrectomy. Retina 1981; 1: 121-149.

32 Char DH, Ljung BM, Miller T, Phillips T. Primary intraocular lymphoma (ocular reticulum cell sarcoma) diagnosis and management. Ophthalmology 1988; 95: 625-630.

33 Scroggs MW, Johnston WW, Klintworth GK. Intraocular tumors. A cytopathologic study. Acta Cytol 1990; 34: 401-408.

34 Intzedy L, Teoh SC, Hogan A, Mangwana S, Mayer EJ, Dick $\mathrm{AD}$ et al. Cytopathological analysis of vitreous in intraocular lymphoma. Eye 2007; e-pub ahead of print.

35 Gonzales JA, Chan CC. Biopsy techniques and yields in diagnosing primary intraocular lymphoma. Int Ophthalmol 2007; 27: 241-250.

36 Cassoux N, Charlotte F, Rao NA, Bodaghi B, Merle-Beral H, Lehoang P. Endoretinal biopsy in establishing the diagnosis of uveitis: a clinicopathologic report of three cases. Ocul Immunol Inflamm 2005; 13: 79-83.

37 Adra CN, Eggerding FA. Diagnostic molecular microbiology in posterior uveitis: principles and applications. Int Ophthalmol Clin 1995; 35: 75-92.

38 Shields JA, Lerner HA, Felberg NT. Aqueous cytology and enzymes in nematode endophthalmitis. Am J Ophthalmol 1977; 84: 319-322.

39 Fardeau C, Romand S, Rao NA, Cassoux N, Bettembourg O, Thulliez $\mathrm{P}$ et al. Diagnosis of toxoplasmic retinochoroiditis with atypical clinical features. Am J Ophthalmol 2002; 134: 196-203.
40 Manku H, McCluskey P. Diagnostic vitreous biopsy in patients with uveitis: a useful investigation? Clin Experiment Ophthalmol 2005; 33: 604-610.

41 Rao NA, Saraswathy S, Smith RE. Tuberculous uveitis: distribution of Mycobacterium tuberculosis in the retinal pigment epithelium. Arch Ophthalmol 2006; 124: 1777-1779.

42 Bodaghi B, Rozenberg F, Cassoux N, Fardeau C, LeHoang P. Non-necrotizing herpetic retinopathies masquerading as severe posterior uveitis. Ophthalmology 2003; 110: 1737-1743.

43 Tran TH, Rozenberg F, Cassoux N, Rao NA, LeHoang P, Bodaghi B. Polymerase chain reaction analysis of aqueous humour samples in necrotising retinitis. Br J Ophthalmol 2003; 87: 79-83.

44 Tran TH, Cassoux N, Bodaghi B, Fardeau C, Caumes E, Lehoang P. Syphilitic uveitis in patients infected with human immunodeficiency virus. Graefes Arch Clin Exp Ophthalmol 2005; 243: 863-869.

45 Gündüz K, Shields JA, Shields CL, Eagle RCJ. Cutaneous melanoma metastatic to the vitreous cavity. Ophthalmology 1998; 105: 600-605.

46 Shankar J, Damato BE, Hiscott P. Palliative vitrectomy for intraocular metastasis from cutaneous melanoma. Eye 2002; 16: $660-662$.

47 Rothova A, Ooijman F, Kerkhoff F, Van Der Lelij A, Lokhorst HM. Uveitis masquerade syndromes. Ophthalmology 2001; 108: 386-399.

48 Read RW, Zamir E, Rao NA. Neoplastic masquerade syndromes. Surv Ophthalmol 2002; 47: 81-124.

49 Coupland SE, Heimann H, Bechrakis NE. Primary intraocular lymphoma: a review of the clinical, histopathological and molecular biological features. Graefes Arch Clin Exp Ophthalmol 2004; 242: 901-913.

50 Calfa CJ, Lossos IS, Ruiz P, Davis JL. Ocular involvement as the initial manifestation of T-cell chronic lymphocytic leukemia. Am J Ophthalmol 2007; 144: 326-329.

51 Chan CC, Wallace DJ. Intraocular lymphoma: update on diagnosis and management. Cancer Control 2004; 11: 285-295.

52 Chan CC, Whitcup SM, Solomon D, Nussenblatt RB. Interleukin-10 in the vitreous of patients with primary intraocular lymphoma. Am J Ophthalmol 1995; 120: 671-673.

53 Merle-Beral H, Davi F, Cassoux N, Baudet S, Colin C, Gourdet $\mathrm{T}$ et al. Biological diagnosis of primary intraocular lymphoma. Br J Haematol 2004; 124: 469-473.

54 Cassoux N, Giron A, Bodaghi B, Tran TH, Baudet S, Davy F et al. IL-10 measurement in aqueous humor for screening patients with suspicion of primary intraocular lymphoma. Invest Ophthalmol Vis Sci 2007; 48: 3253-3259.

55 Coupland SE, Foss HD, Hidayat AA, Cockerham GC, Hummel M, Stein H. Extranodal marginal zone B cell lymphomas of the uvea: an analysis of 13 cases. J Pathol 2002; 197: 333-340.

56 Coupland SE, Damato B. Lymphomas involving the eye and the ocular adnexa. Curr Opin Ophthalmol 2006; 17: 523-531.

57 Whitcup SM, Chan CC, Buggage RR, Nussenblatt RB, Byrnes GA, Rubin BI. Improving the diagnostic yield of vitrectomy for intraocular lymphoma. Arch Ophthalmol 2000; 118: 446. 